\title{
Vitamin D: A Review on Functions and Requirements (Part II)
}

\author{
Authors \\ Dr Vishakha S. Patil ${ }^{1}$, Dr Rohini S. Mali ${ }^{2}$, Dr Alpana Moghe ${ }^{3}$ \\ ${ }^{1}$ Dept of Periodontology, Bharati Vidyapeeth Deemed University, Dental College and Hospital, Pune, India \\ Email:drvishakhap@gmail.com \\ ${ }^{2}$ Dept of Periodontology, Bharati Vidyapeeth Deemed University, Dental College and Hospital, Pune, India \\ Email: rohinimali4@gmail.com \\ ${ }^{3}$ Dept of Cell and Molecular Biology, Rajiv Ganghi Institute of Information, Technology and \\ Biotechnology, Bharati Vidyapeeth Deemed University, Pune, India
}

Email: alpanasm@gmail.com

\begin{abstract}
Vitamin D a fat soluble vitamin is also a hormone which along with its effect on bone mineralization, exerts its effect on cells by binding to Vitamin $D$ receptor present on most cell types in the body. Its broad spectrum of activities in skin, immune system, cell differentiation and development underlines its crucial role in regulation of metabolism. The present review is an attempt to provide compiled information on the crucial role played by this vitamin in controlling the functions of body tissues. This review also highlights necessary intake values, dietary sources, normal serum levels and toxicity associated with excess intake. The review article intends to spread the knowledge that vitamin $D$ is absolutely critical for good health and disease prevention.
\end{abstract}

Keywords- Inactive Vitamin $D_{3}$, Calcitriol, Vitamin D deficiency, Immune response, Cancer prevention.

\section{INTRODUCTION}

Advanced knowledge of the biological and clinical importance of the steroid hormone 1,25dihydroxyvitamin D3 [1,25(OH)2D3] and its receptor, the Vitamin D Receptor (VDR), has resulted in significant contributions to good bone health. Over the past several decades, the biological sphere of influence of Vitamin D3, as defined by the tissue distribution of the VDR, has broadened at least 9-fold from the target organs required for calcium homeostasis (intestine, bone, kidney, and parathyroid). Now, research has shown that the pluripotent steroid hormone1,25(OH)2D3 initiates the physiologic responses of 36 cell types that possess the VDR. Thus new biological actions of
1,25 (OH)2D3 through the VDR has been identified. An attempt is made in this article to review all the actions of Vitamin D3. Also requirements and sources of Vitamin D3 are highlighted. So that, one gets an idea about the necessity of this hormone for proper functioning of our body.

\section{FUNCTIONS OF VITAMIN D3}

The mechanism by which an active Vitamin $1 \alpha$ $25(\mathrm{OH})_{2} \mathrm{D}_{3}$ exerts its effects has been extensively investigated. The Vitamin D system shows similar features like other ligand activated nuclear receptors such as the retinoic acid receptor (RAR) and thyroid hormone receptor (TR). ${ }^{1}$ The biological effects of $1 \alpha$ $25(\mathrm{OH})_{2} \mathrm{D}_{3}$ (Ligand) are mediated via binding to the 
Vitamin D Receptor (VDR). Vitamin D Receptor (VDR) is a member of the steroid nuclear receptor super family found in Vitamin D targets. The VDR gene is positioned on human chromosome 12q. VDR can be divided by function into different domains (Figure I).

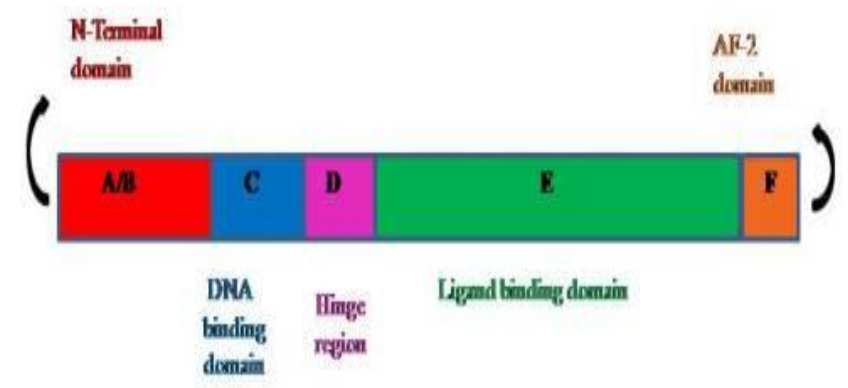

FIGURE I-VDR Demains

Amongst these domains the ligand binding domain is responsible for high affinity binding of ligand. Upon ligand binding the receptor dimerizes with retinoid $\mathrm{X}$ receptor (RXR). This complex binds to Vitamin D Responsive elements (VDRE) within the promoter regions of Vitamin D response genes (Figure II). Other proteins responsible for transcription are recruited and thus transcription takes place. Depending on co-activators or corepressors transcriptional activity is either upregulated or downregulated. $^{2}$

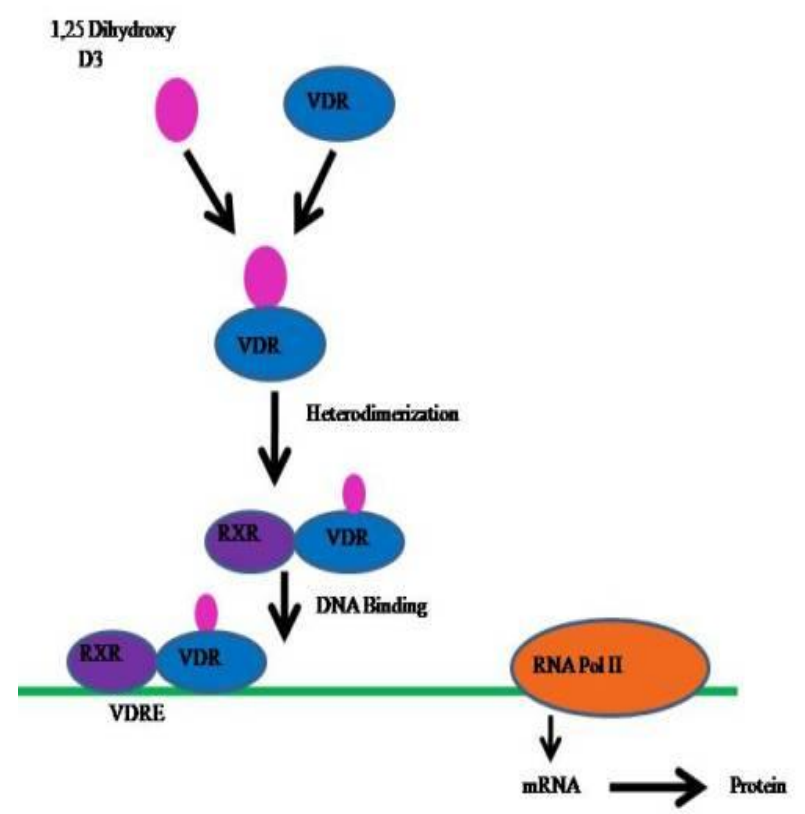

FIGURE II- BIOLOGICAL RESPONSE OF VITAMIN D3

VDR: Vitamin D Receptor, RXR: Retinoid X Receptor, VDRE: Vitamin D Responsive Element, RNA Pol II: RNA polymerase II

\section{Mineralization of Skeleton}

Vitamin D causes bone mineralization by the elevation of plasma calcium and phosphorus concentrations. ${ }^{3}$ A major function of $1 \alpha 25(\mathrm{OH})_{2} \mathrm{D}_{3}$ is that it promotes intestinal absorption of calcium and phosphate. Along with PTH it also initiates the renal reabsorption of calcium in the distal tubule. ${ }^{4}$ The above sources of calcium result in rise in blood calcium for support of mineralization and prevention of hypocalcemic tetany. $1 \alpha 25(\mathrm{OH})_{2} \mathrm{D}_{3}$ may also have direct effects on the bone. ${ }^{5}$ In vitro studies have shown that $1 \alpha \quad 25(\mathrm{OH})_{2} \quad \mathrm{D}_{3}$ stimulates osteoblasts, to differentiate and deposit calcified matrix. ${ }^{6}$ The calcium concentration in blood is held constantly at $1 \mathrm{mmol}$ ionized calcium or $10 \mathrm{mg} / 100$ $\mathrm{ml}$ of total calcium. However when dietary sources are inadequate to maintain normocalcemia, 1,25$(\mathrm{OH})_{2} \mathrm{D}_{3}$ stimulates calcium mobilization from the bone by promoting the differentiation of precursor cells into mature, bone-resorbing osteoclasts. ${ }^{7}$ The development of the giant osteoclast, plays a major role in bone remodeling, and bone resorption. ${ }^{8}$ Vitamin D along with parathyroid hormone (PTH) stimulates osteoclast-mediated bone resorption. ${ }^{9}$ Vitamin D and the PTH, as well as other factors, s timulate the transcription and production of RANKL, the ligand for the NFkB receptor. When this occurs, the osteoclast precursors are converted to mononuclear prefusion osteoclasts that differentiate and then become activated osteoclasts.

\section{Regulation of Immunity}

Vitamin D hormone is an immune system modulator, it stimulates the innate immune response in antigen presenting cells like macrophages and dendritic cells. When activated nonspecifically with mitogen or specifically with antigen, the macrophage becomes a target for vitamin $\mathrm{D}$ by expressing VDR and promotes antigen processing, phagocytosis, superoxide synthesis, interleukin 1 beta and tumor necrosis factor alpha production, to rid the host of the offending agent. ${ }^{10}$ Like the macrophage, mitogen or antigen activated lymphocytes also express the VDR. ${ }^{10}$ VDR regulates the production of T-Cell helper 1 and 2 cytokines 
and IL-17 thus influencing adaptive immunity and inflammation. ${ }^{11}$ The TH1 cytokine interferon $\gamma$ enhances the TLR2/1 induction of CYP27 B1, Cathelicidin. Cathelicidin have significant broad antimicrobial activity against both gram positive and gram negative bacteria. ${ }^{12} .1,25$ dihydroxyvitamin $\mathrm{D}_{3}$ induces antimicrobial peptide gene expression in isolated human keratinocytes, monocytes and neutrophils and human cell lines. ${ }^{13}$

\section{Role in maintaining Periodontal health}

Periodontitis even though is multifactorial disease, presence of specific bacteria and host immune response to bacterial insult is required for disease initiation and progression. It is characterized by alveolar bone loss. Both genetic and environmental factors enhance susceptibility to Periodontal disease. ${ }^{14}$ Because vitamin D plays a role in bone maintenance and immunity there is biologic rationale to suspect that Vitamin D deficiency could negatively affect the Periodontium. From the Analysis of data of NHANES III (National health and Nutrition Examination Survey), it was revealed that higher levels of $25(\mathrm{OH}) \mathrm{D}_{3}$ reduced the risk of gingival inflammation by exerting antiInflammatory effects. ${ }^{15}$ In a study by Garcia et al 2011, ${ }^{16}$ Periodontal maintenance subjects taking calcium and Vitamin D supplements showed better periodontal health. As alveolar bone loss is a key feature in periodontitis some association studies involving Vitamin D Receptor have been conducted. ${ }^{17,18}$ considering the immunomodulatory effect of Vitamin D, it can be applied to periodontal health. ${ }^{19}$

\section{Differentiation of cells:}

The first important breakthrough was in 1981 when it was demonstrated that terminal differentiation of promyelocytes to the monocyte could be brought about by the Vitamin D hormone. ${ }^{20}$ Along with differentiation of the promyelocytes it suppressed proliferation of those cells. This may be related to suppression of certain significant cell cycle proteins. $^{21}$ The $1,25(\mathrm{OH})_{2} \mathrm{D}_{3}$ inhibits the growth of various normal as well as cancerous cell types by blocking G1/S transition which causes G1 phase cells to accumulate and accordingly S-Phase cell numbers to decrease. ${ }^{22,23}$ It has been shown to cause $\mathrm{G} 2 / \mathrm{M}$ arrest. ${ }^{24}$ Along with its effect on different cell cycle regulators, $\quad 1,25(\mathrm{OH})_{2} \mathrm{D}_{3}$ also controls genomic stability. The fact that cancer cell growth suppression and differentiation induced by $1,25(\mathrm{OH})_{2} \mathrm{D}_{3}$ has raised the hope that $1,25(\mathrm{OH})_{2} \mathrm{D}_{3}$, or an analog, may be useful in the treatment of malignant disease. ${ }^{25}$

\section{Role in Reproduction}

Ovarian cells have been found to contain VDR. ${ }^{26}$ Furthermore, ovarian cells in vivo also accumulate $1,25(\mathrm{OH})_{2} \mathrm{D}_{3}{ }^{27}$ It has been suggested that the ovary therefore is a target of Vitamin D action.

\section{Role in Skin}

Hosomi et al in $1983{ }^{28}$ provided the first In-Vitro report that $1,25(\mathrm{OH})_{2} \mathrm{D}_{3}$ induces keratinocyte differentiation. Holick and co-workers ${ }^{29}$ also gave similar reports. Hyperproliferation of the keratinocyte and failure to differentiate was not found in Vitamin D-deficient animals 30 Differentiation property of $1,25(\mathrm{OH})_{2} \mathrm{D}_{3}$ has been utilized in the treatment of hyperproliferative diseases of skin such as psoriasis. ${ }^{31}$ During the differentiation process, it was found that there is an increase in the protein involukrin, ${ }^{32}$ transglutamase activity ${ }^{32}$ and cornified envelope formation. ${ }^{33}$ The $1,25(\mathrm{OH})_{2} \mathrm{D}_{3}$ produced by the keratinocyte itself, stimulate its differentiation. ${ }^{34}$

\section{Other Actions}

One more interesting area is autoimmune disease. In 1993 Yang S et al demonstrated that Vitamin D suppresses delayed hypersensitivity response. ${ }^{35}$ In an experimental model of multiple sclerosis, super physiologic amounts of $1,25(\mathrm{OH})_{2} \mathrm{D}_{3}$ completely blocked experimental autoimmune encephalomyelitis. ${ }^{36}$ Rheumatoid arthritis could also be suppressed by $1,25(\mathrm{OH})_{2} \mathrm{D}_{3} .{ }^{37}$ Vitamin D hormone also helped block type I diabetes in the non-obese diabetic mouse. $^{38}$ 


\section{REQUIREMENT AND SOURCES}

Federal Governments Institute of Medicine (IOM) Food and Nutrition Board (Washington, DC ${ }^{39}$ ) at the end of 2010, proposed some improved recommendations (Table I). It increased the recommended dietary allowance for most adults from 200-600 IU (up to $800 \mathrm{IU}$ for those 71 and older) to maintain healthy bones.

Table I: Vitamin D Dietary Reference Intakes

\begin{tabular}{|c|c|c|c|c|}
\hline \multicolumn{5}{|c|}{ Vitamin D Dietary Reference Intakes } \\
\hline $\begin{array}{l}\text { Sr. } \\
\text { No }\end{array}$ & Life Stage Group & EAR & RDA & $\mathbf{U L}$ \\
\hline 1. & $\begin{array}{lll}\text { Male } & 19-30 & \text { Years } \\
\text { Old } & & \end{array}$ & $400 \mathrm{IU}$ & $600 \mathrm{IU}$ & $4000 \mathrm{IU}$ \\
\hline 2. & $\begin{array}{lll}\text { Male } & 31-50 & \text { Years } \\
\text { Old } & & \\
\end{array}$ & $400 \mathrm{IU}$ & $600 \mathrm{IU}$ & $4000 \mathrm{IU}$ \\
\hline 3. & $\begin{array}{lll}\text { Male } & 51-70 & \text { Years } \\
\text { Old } & & \\
\end{array}$ & $400 \mathrm{IU}$ & $600 \mathrm{IU}$ & $4000 \mathrm{IU}$ \\
\hline 4. & $\begin{array}{l}\text { Male above } 70 \text { Years } \\
\text { of Age }\end{array}$ & $400 \mathrm{IU}$ & $800 \mathrm{IU}$ & $4000 \mathrm{IU}$ \\
\hline 5. & $\begin{array}{l}\text { Female 19-30 Years } \\
\text { Old }\end{array}$ & $400 \mathrm{IU}$ & $600 \mathrm{IU}$ & $4000 \mathrm{IU}$ \\
\hline 6. & $\begin{array}{l}\text { Female } 31-50 \text { Years } \\
\text { Old }\end{array}$ & $400 \mathrm{IU}$ & $600 \mathrm{IU}$ & $4000 \mathrm{IU}$ \\
\hline 7. & $\begin{array}{l}\text { Female 51-70 Years } \\
\text { Old }\end{array}$ & $400 \mathrm{IU}$ & $600 \mathrm{IU}$ & $4000 \mathrm{IU}$ \\
\hline 8. & $\begin{array}{l}\text { Female above } 70 \\
\text { Years Age }\end{array}$ & $400 \mathrm{IU}$ & $800 \mathrm{IU}$ & $4000 \mathrm{IU}$ \\
\hline
\end{tabular}

EAR: Estimated Average Requirement (Intake that meets needs of $50 \%$ of individual).

RDA: Recommended dietary Allowance (Intake that meets the needs of $97 \%$ to $98 \%$ of Individuals).

UL: Tolerable Upper Intake Level (Highest level of Intake that poses no adverse effects).

IU: International Units.

In the light of new research RDA guidelines are not sufficient. More units of Vitamin D are required every day to prevent risk of infection, cancer and various diseases.

In a conference held on November $3^{\text {rd }} 2009$ at University of Toronto, Ontario, Canada, Robert $\mathrm{P}$ Heaney, Reinhold Vieth, John White and Susan Whiting $^{40}$ had suggested Vitamin D recommendations as follows:
Table II: Vitamin D Recommendations

\begin{tabular}{|l|c|c|}
\hline \multicolumn{3}{|c|}{ Vitamin D Recommendations } \\
\hline Sr. No & Age & Dosage \\
\hline 1 & Below 5 & 35 Units per pound per day \\
\hline 2 & Age 5-10 & 2500 Units \\
\hline 3 & Adults & 4000-8000 Units \\
\hline 4 & Pregnant Women & $5000-10000$ Units \\
\hline
\end{tabular}

Based on the most recent research, the current recommendation is 35 IUs of Vitamin D per pound of body weight. Bischoff-Ferrari HA in $2006^{41}$ indicated that the desirable $25(\mathrm{OH}) \mathrm{D}$ concentration is $\_75 \mathrm{nmol} / \mathrm{L}$. Cholecalciferol (Vitamin $\mathrm{D}_{3}$ ) is more potent than ergocalciferol (Vitamin $\mathrm{D}_{2}$ ) and the safe upper intake level for Vitamin $\mathrm{D}_{3}$ is $10,000 \mathrm{IU} / \mathrm{d}$.

However Vitamin D requirements differ for each individual as Vitamin D status is dependent on numerous factors which affect absorption or production of Vitamin $\mathrm{D}_{3}$ through skin. When skin is exposed to UV rays, precholecalciferol is formed which can isomerizes to cholecalciferol or photoisomerize into biologically inactive photoisomers, lumisterol and tachysterol. ${ }^{42}$ Melanin pigmentation reduces the efficiency of sun mediated photosynthesis of precholecalciferol. ${ }^{43,44}$ Age is another factor which declines production of adequate amounts of Vitamin $\mathrm{D}_{3}$. Application of sunscreen also prevents cutaneous production of precholecalciferol. ${ }^{45}$ Covering of skin with any type of clothing in any season prevents cutaneous production of cholecalciferol. ${ }^{46}$

Apart from its production in the skin, Vitamin $\mathrm{D}_{3}$ has some dietary sources. The food sources are as follows: ${ }^{47}$

Table III: Food Sources

\begin{tabular}{|l|l|l|}
\hline \multicolumn{2}{|l|}{ Food Sources } \\
\hline $\begin{array}{l}\text { Sr. } \\
\text { No }\end{array}$ & Food sources & $\begin{array}{l}\text { Quantity } \\
\text { (IU) }\end{array}$ \\
\hline 1. & $\begin{array}{l}\text { Oily fish and Fish liver oils } \\
\text { (Cod Liver oil)(Best source) }-1 \text { tbs }\end{array}$ & $1360 \mathrm{IU}$ \\
\hline 2. & Sword Fish cooked $3 \mathrm{oz}$ & $566 \mathrm{IU}$ \\
\hline 3. & Salmon cooked 3 oz & $447 \mathrm{IU}$ \\
\hline 4. & Liver, Beef cooked 3.5 oz & $42 \mathrm{IU}$ \\
\hline 5. & Egg 1whole (In the yolk) & $41 \mathrm{IU}$ \\
\hline 6. & Cheese (Swiss) $1 \mathrm{oz}$ & $06 \mathrm{IU}$ \\
\hline
\end{tabular}

IU : International Unit, tbs : Table spoon, oz :Ounces 
As Vitamin $D_{3}$ is fat soluble its absorption can be enhanced using nutritional oils like Flaxseed oil, evening Primrose oil, or fish oils in the diet. Subjects with chronic fat absorption problems should be investigated for Vitamin $\mathrm{D}$ and bone status. Use of Olestra diminishes absorption of fat soluble Vitamins A, D, E and K. Magnesium supplementation is required to convert Vitamin $\mathrm{D}_{2}$ to $\mathrm{D}_{3}$. It also acts as enzyme cofactor for converting cholecalciferol to Inactive and Active form of Vitamin $\mathrm{D}_{3}$. Vitamin $\mathrm{D}$ absorption and /or metabolism are also interfered by Bile acid sequestrants like cholestyramine, corticosteroids, dilantin, barbiturates, phenobarbital, etidronate, tuberculosis drugs and mineral oils.

\section{SERUM LEVELS}

The normal Levels of 25 Hydroxy $\mathrm{D}_{3}$ in blood are 30 $\mathrm{ng} / \mathrm{ml}(75 \mathrm{nM})$ to $60 \mathrm{ng} / \mathrm{ml}(150 \mathrm{nM})$. Serum concentration of 25-hydroxyvitamin $\mathrm{D}_{3}$ from $21-$ $29 \mathrm{ng} / \mathrm{ml}$ is considered Insufficient and levels below $20 \mathrm{ng} / \mathrm{ml}(50 \mathrm{nM})$ are considered serious deficiency states. Levels greater than $150 \mathrm{ng} / \mathrm{ml}(374 \mathrm{nM})$ are believed to be toxic, and are associated with hypercalcemia, hypercalciuria and, hyperphosphatemia. ${ }^{48}$ A review by Hathcock JN et al ${ }^{49}$ in 2007 has discussed the risk assessment for Vitamin D. They focused on the risk of hypercalcemia and concluded that the Upper Intake Level (UL) for Vitamin D consumption by adults should be 10000 IU/d thus margin of safety for Vitamin D consumption for adults is more than 10 times any current recommended intakes.

\section{TOXICITY}

Following World War II, an outbreak of idiopathic hypercalcemia and related arterial supravascular stenosis was attributed to food fortification with Vitamin D. ${ }^{50}$ Certainly, Vitamin D is potentially toxic when provided in large amounts. Toxicity results in hypercalcemia, nephrocalcinosis, aortic calcification, and other unwanted deposits of calcium and phosphorus in soft tissues. ${ }^{51}$ A report indicated that 10,000 units of Vitamin $\mathrm{D}_{3}$ per day is safe for 6 Months, ${ }^{53}$ but we must remember that Vitamin D itself is stored and the danger of it accumulating in the adipose tissue and possibly resulting in toxicity in the future must be investigated.

\section{CONCLUSION}

The research on Vitamin $D$ has increased tremendously. Vitamin D deficiency and insufficiency is pandemic and seen in essentially every country in the world. Lack of awareness about the importance of this deficiency has become very crucial. Its deficiency has led to increased risk of the most serious chronic illnesses such as cancer, type 2 diabetes, autoimmune diseases and infectious diseases in the world's population. Awareness is required in the medical community and public about the insidious consequences of Vitamin D deficiency. As there are very limited food sources and less exposure of skin to sun, daily intake is recommended. Importance of Vitamin D adequacy will definitely have a dramatic impact on the health and welfare of all children and adults and people should consume fortified food or should be given supplements of Vitamin D perhaps to ensure adequacy of essential element especially Vitamin D.

\section{REFERENCES}

1. Evans R M (1998). The steroid and thyroid hormone receptor superfamily. Science 40: 889-895.

2. Mark R, Haussler MR, Haussler et al (2011). Vitamin D receptor (VDR)-mediated actions of 1 $\alpha, 25(\mathrm{OH}) 2 \mathrm{D} 3$ : Genomic and nongenomic mechanisms. Best Practice \& Research Clinical Endocrinology \& Metabolism 25: 543-559.

3. DeLuca HF Ed (1979). Vitamin D. Metabolism and function. In DeLuca HF Ed. Monographs on Endocrinology. Berlin: Springer-Verlag Pg. 1-80.

4. Yamamoto M, Kawanoke Y, Takahashi H, Shimazawa E, Kimura S, Ogata E (1984). Vitamin D deficiency and renal calcium 
transport in the rat. J Clin Invest 74: $507-$ 553.

5. Van Leeuwen JP, Van Driel M, Van den Bemd GJ, Pols HA (2001) Vitamin D control of osteoblast function and bone extracellular matrix mineralization. Crit Rev Eukaryot Gene Expr 11:199-226.

6. Owen TA, Aronow MS, Barone LM, Bettencourt B, Stein GS, Lian JB (1991). Pleiotropic effects of Vitamin D on osteoblast gene expression are related to the proliferative and differentiated state of the bone cell phenotype: dependency upon basal levels of gene expression, duration of exposure, and bone matrix competency in normal rat osteoblast cultures. Endocrinology 128:1496-1504.

7. Bar-Shavit Z, Teitelbaum SL, Reitsma P, Hall A, Pegg LE, Trial J, Kahn AJ (1983). Induction of monocytic differentiation and bone resorption by 1,25-dihydroxyvitamin D3. Proc Natl Acad Sci USA 80:5907-5911.

8. Yasuda H, Kigashio K, Suda $T$ (2005). Vitamin D and osteoclastogenesis. In: Feldman D, Pike JW, Glorieux FH, eds. Vitamin D 2nd edn. San Diego, C.A: Elsevier Academic Press; 665-685.

9. Garabedian M, Tanaka Y, Holick MF, DeLuca HF (1974). Response of intestinal calcium transport and bone calcium mobilization to 1,25-dihydroxyvitamin D3 in thyroparathyroidectomized rats. Endocrinology 94:1022-1027.

10. Adams JS, Hewison M (2008). Unexpected actions of Vitamin D: new perspectives on the regulation of innate and adaptive immunity. Nat Clin Pract Endocrinol Metab 4:80-90.

11. Tiosano D, Wildbaum G, Gepstein V, Verbitsky O, Weisman Y et Al (2013). The role of vitamin $\mathrm{D}$ receptor in innate and adaptive immunity: Astudy in hereditary Vitamin D resistant Rickets patients. J Clin Endocrinol Metab 98: 1685-1693.
12. Liu PT, Stenger S, Wenzel L et al (2006). Activation of human TLR2/1 t triggers a Vitamin D receptor-dependent antimicrobial response. Science 311:1770-1773.

13. Tian-Tian Wang, Frederick P. Nestel, Veronique Bourdeau et al (2004). Cutting edge: 1, 25-Dihydroxyvitamin D3 Is a direct Inducer of Antimicrobial peptide gene expression. The Journal of Immunology 173: 2909-2912.

14. Holla LI, Jurajda M, Fassmann A, Dvorakova N, Znojil V, Vacha J (2004). Genetic variations in the matrix mettaloproteinase-1 promoter and risk of susceptibility and/or severity of Chronic Periodontitis in the Czech population. J Clin Periodontol 31:685-90.

15. Dietrich T, Nunn M, Dawson-Hughes B, Bischoff- Ferrari HA (2005).Association between serum concentrations of 25hydroxyvitamin $\mathrm{D}$ and gingival inflammation. Am J Clin Nutr 82: 575-580.

16. Garcia MN, Hildebolt CF, Miley DD, Dixon Da, Couture RA, Spearie CL, et al (2011).One Year effects of Vitamin D and calcium supplementation on Chronic Periodontitis. J Periodontol 82: 25-32.

17. Naito M, Miyaki K, Naito T, Zhang L, Hoshi K Hara A et al (2007). Association between Vitamin D receptor gene haplotypes and Chronic Periodontitis among Japanese men. Int J Med Sci.4(4):216-22.

18. Park KS, Nam JH, Choi J (2006). The short Vitamin D Receptor is associated with increased risk for generalized aggressive Periodontitis. J Clin Periodontol 33(8): 5248.

19. Anand N. Chandrasekaran SC, Rajput NS. Vitamin D and Periodontal health. Current concepts. J Indian Soc Periodontol 17: 302308.

20. Abe E, Miura C, Sakagami H, et al (1981). Differentiation of mouse myeloid leukemia cells induced by 1a,25-dihydroxyvitamin D3. Proc Natl Acad Sci USA 78:4990-4994. 
21. Wilson AJ, Velcich A, Arango D, et al (2002). Novel detection and differential utilization of a c-myc transcriptional block in colon cancer chemoprevention. Cancer Res 62: 6006-6010.

22. Wang QM, Jones JB, Studzinski GP (1996). Cyclin- dependent kinase inhibitor p27 as a mediator of the G1-S phase block induced by1,25-dihydroxyvitamin D3 in HL60 cells. Cancer Res 56:264-267.

23. Verlinden L, Verstuyf A, Convents R, Marcelis S, Van Camp M, Bouillon R (1998). Action of 1,25(OH)2D3 on the cell cycle genes, cyclin D1, p21 and p27 in MCF-7 cells. Mol Cell Endocrinol 142:5765.

24. Godyn H J, Xu J, Zhang F, Kolla S, Studzinski GP (1994). A dual block to cell cycle progression in HL 60 cells exposed to analogues of Vitamin D3. Cell Prolif 27: 37 46.

25. Eisman JA, Koga M, Sutherland RL, Barkla DH, Tutton PJM (1989). 1,25-Dihydroxyvitamin D3 and the regulation of human cancer cell replication. Proc Soc Exp Biol Med 191:221-226.

26. Dokoh S, Donaldson CA, Marion SL, Pike JW, Haussler MR (1983). The ovary: a target organ for 1,25-dihydroxyvitamin $\mathrm{D}_{3}$ Endocrinology 112:200-206.

27. Stumpf WE, Sar M, and Reid FA(1979). Target cells for 1,25-dihydroxyvitamin D3 in intestinal tract, stomach, kidney, skin, pituitary and parathyroid. Science 206:1188-1190.

28. Hosomi J, Hosoi J, Abe E, Suda T, Kuroki T (1983). Regulation of terminal differentiation of cultured mouse epidermal cells by a,25-dihydroxyvitamin $\quad \mathrm{D}_{3}$.Endocrinology 113:1950-1957.

29. Holick MF, Smith EL, Walworth NC (1986). Effect of 1 1 ,25-dihydroxyvitamin $\mathrm{D}_{3}$ on the morphologic and biochemical differentiation of cultured human epidermal keratinocytes grown in serum-free conditions. J Invest Dermatol 86:709-714.

30. DeLuca HF (1971). Active compounds. In: The Vitamins Chemistry, Physiology, Pathology, Methods, edited by WH Sebrell Jr, and RS Harris. New York: Academic chap. IV, pp 223-232.

31. Hosomi J, Hosoi J, Abe E, Suda T, Kuroki, T (1983). Regulation of terminal differentiation of cultured mouse epidermal cells by $1 \alpha, 25$ dihydroxyvitamin $\quad \mathrm{D}_{3}$. Endocrinology 113:1950-1957.

32. Sum J, Bikle DD, Mancianti ML, Pillai S (1994). 1,25-Dihydroxyvitamin $\quad \mathrm{D}_{3}$ potentiates the keratinocyte response to calcium. J Biol Chem 269:14723-14729.

33. Pillai S, Bikle DD (1991). Role of intracellular free calcium in the cornified envelope formation of keratinocytes: differences in the mode of action of extracellular calcium and 1,25 dihydroxyvitamin D. J Cell Physiol 146:94100.

34. Bikle DD (1997). Vitamin D and skin. In: Vitamin D edited by Feldman D, Glorieux FH, and Pike JW, San Diego CA: Academic, chap. 25, pp 379-394.

35. Yang S, Smith C, Prahl JM, DeLuca HF (1993). Vitamin D deficiency suppresses cell-mediated immunity in vivo. Arch Biochem Biophys 303:98-106.

36. Cantorna MT, Hayes CE, DeLuca HF (1996). 1,25- Dihydroxyvitamin D3 reversibly blocks the progression of relapsing encephalomyelitis, a model of multiple sclerosis. Proc Natl Acad Sci USA 93:7861- 7864.

37. Cantorna MT, Hayes CE, DeLuca HF (1998). 1,25- Dihydroxycholecalciferol inhibits the progression of arthritis in murine models of human arthritis. J Nutr 128:6872.

38. Zella JB, McCary LC, DeLuca HF (2003). Oral administration of 1,25dihydroxyvitamin D3 completely protects 
NOD mice from insulin- dependent diabetes mellitus. Arch Biochem Biophys 417:77-80.

39. Institute of Medicine. Dietary reference intakes for calcium and Vitamin D. Washington,DC: Institute of Medicine of the National Academies. 2010.

40. Vitamin D- The Master Key to Optimal Health by Dr. Robert Heaney 2009. Visit Mercola Video Library online Reference.

41. Bischoff-Ferrari HA, Giovannucci E, Willett WC, Dietrich T, Dawson-Hughes B (2006). Estimation of optimal serum concentrations of 25-hydroxyvitamin D for multiple health outcomes. Am J Clin Nutr 84:18 -28.

42. Holick MF, Mac Laughlin JA, Doppelt SH (1981). Factors that influence the cutaneous photosynthesis of previtamin D3. Science 211: 590-3.

43. Webb AR, de Costa BR, Holick MF (1989). Sunlight regulates the cutaneous production of Vitamin D3 by causing its photodegradation. J Clin Endocrinol Metab 68:882-7.

44. Clemens TL, Adams JS, Henderson SL, Holick MF (1982).Increased skin pigment reduces the capacity of the skin to synthesize Vitamin D. Lancet 1:74-6.

45. Matsuoka LY, Ide L, Wortsman J, MacLaughlin JA, Holick MF (1987). Sunscreens suppress cutaneous Vitamin D synthesis. J Clin Endocrinol Metab 64:11658.

46. Matsuoka LY, Wortsman J, Dannen Berg MJ, Hollis BW, Lu Z,Holick MF (1992).Clothing prevents ultraviolet B radiation -dependent photosynthesis of Vitamin D3. J Clin Endocrinol Metab 75:1099-103.

47. Suellan Go Yao, James Burke Fine (2012). A Review of Vitamin D as It Relates to Periodontal Disease. Compendium of Continuing Education In Dentistry.

48. Holick MF (2009). Vitamin D Status: Measurement, Interpretation, and Clinical Application. Ann Epidemiol 19 (2): 73-78.
49. Hathcock JN, Shao A, Vieth R, Heaney R (2007). Risk assessment for Vitamin D. Am J Clin Nutr 85: 6 -18.

50. Marx SJ (1995). Vitamin D and other calciferols. In:Scriver CR, Beaudet AL, Sly WS, Valle D, editors. The Metabolic and Molecular Bases of Inherited Disease. Vol. 2, 7th ed. New York: McGraw-Hill, pp 3103-3104.

51. Kramer B, Kanof A (1954). VIII. Requirements of human beings. In: Sebrell Jr WH, Harris RS, editors. The Vitamins. Chemistry, Physiology, Pathology. Vol. II. NewYork: Academic Pres, pp257-266.

52. Hathcock JN, Shao A, Vieth R, Heaney R (2007). Risk assessment for Vitamin D. Am J Clin Nutr. 85:6-18.

\section{ABBREVIATIONS AND ACRONYMS}

$1 \alpha 25(\mathrm{OH})_{2} \mathrm{D}_{3}-1 \alpha 25$ dihydroxy D3

RAR - Retinoic Acid Receptor

TR - Thyroid hormone Receptor

VDR - Vitamin D Receptor

RXR - Retinoid X Receptor

VDRE - Vitamin D Responsive Element

RNA Pol II - Ribonucleic Acid polymerase II

mRNA - Messenger Ribonucleic Acid

PTH - Parathyroid Hormone

mmol - Milli mole

mg - Milligram

$\mathrm{ml}$ - Millilitre

RANKL - Receptor activator of nuclear factor kappa- B ligand

NFkB - Nuclear Factor kappa-light-chain enhancer of activated B cells

IL17 - Interleukin 17

TH1 - T helper 1

$\gamma$ - Gamma

TLR - Toll like receptors

CYP 27 - Cytochrome P 27

NHANES - National Health and Nutrition Examination Survey

IU - International Units

IOM - Institute of Medicine

EAR - Estimated Average Requirement 
RDA - Recommended Dietary Allowances

UL - Tolerable Upper Intake Level $\mathrm{nm} / \mathrm{L}$ - Nano mole/ Litre

IU/d - International Unit / Decilitre

UV rays- Ultraviolet rays

tbs - Table spoon

$\mathrm{Oz}$ - Ounces

$\mathrm{ng} / \mathrm{ml}$ - Nano gram/ millilitre

nM - Nano Mole 